\title{
Modulation of hippocampal gamma oscillations by acetylcholine: insights from mathematical and in vitro optogenetic models
}

\author{
Ruth Betterton ${ }^{1 *}$, Jack Mellor ${ }^{1}$, Krasimira Tsaneva-Atanasova ${ }^{2}$ \\ From 24th Annual Computational Neuroscience Meeting: CNS*2015 \\ Prague, Czech Republic. 18-23 July 2015
}

A neuronal oscillation involves the rhythmic, synchronous firing of a population of cells. Oscillations found throughout the cortex can be separated into bands of differing frequencies which are associated with various behavioural states. Gamma oscillations $(30-100 \mathrm{~Hz})$ occur coincidently with attention, sensory processing and learning and memory. The hippocampus, known for its role in learning and memory, shows gamma activity in vivo [1] and gamma oscillations can be induced in in vitro slices [2]. The release of acetylcholine (ACh) correlates with increases in oscillatory power in vivo [3] and knockout of specific ACh receptor subtypes provides evidence for this scenario [4]. To further investigate the role of $\mathrm{ACh}$ in the modulation of gamma oscillations we have utilised both in vitro and computational techniques.

We implemented a mathematical model of the CA3 region of the hippocampus based on [5]. Using Hodgkin-Huxley single compartmental neurons, we verify that a network of 80 excitatory pyramidal cells and 20 inhibitory interneurons is able to produce oscillatory activity within the gamma range.

We developed an optogenetic system (see $[6,7]$ ) to induce gamma oscillations enabling us to test modulation by specific acetylcholine receptors. Male mice received stereotaxic injection into the CA3 region of the hippocampus of a viral vector (AAV5) containing channelrhodopsin (hChR2(H134R)) under the control of the CaMKII $\alpha$ promoter. Stimulation of the ChR expressing CA3 pyramidal cell bodies with short light pulses (5-50 ms) evoked action potentials and stimulation of Schaffer collateral axons

\footnotetext{
* Correspondence: r.betterton@bristol.ac.uk

'School of Physiology and Pharmacology, University of Bristol, Bristol, BS8 ITD, UK

Full list of author information is available at the end of the article
}

elicited robust synaptic responses in the CA3 and CA1 regions that were blocked by the application of NBQX $(10 \mu \mathrm{M})$ or TTX $(1 \mu \mathrm{M})$. Local field potential recordings showed that a 1s step optical stimulation induced low power and low frequency gamma oscillations which attenuated over time. In vivo, gamma oscillations are often found 'nested' within an overlying theta oscillation [8]. Correlating well with these in vivo recordings, theta frequency $(5 \mathrm{~Hz})$ sine wave optical stimulation induced higher power and higher frequency gamma oscillations with less attenuation over a 1 s period.

We introduced, a similar, $5 \mathrm{~Hz}$ sine depolarising input to the pyramidal cells in our mathematical model and found that it was able to induce oscillations at gamma frequency.

By manipulating specific currents within the model, we predicted the effect of specific ACh receptor subtype activation on gamma oscillations. These predictions were supported by our in vitro experimental evidence showing that we found that activation of ACh receptors did indeed modulate gamma oscillations with M1 receptor having a major effect.

\section{Authors' details \\ ${ }^{1}$ School of Physiology and Pharmacology, University of Bristol, Bristol, BS8 1TD, UK. ${ }^{2}$ College of Engineering, Mathematics and Physical Sciences, University of Exeter, Exeter, EX4 4QF, UK.}

Published: 18 December 2015

\section{References}

1. Csicsvari J, Jamieson B, Wise KD, Buzsáki G: Mechanisms of gamma oscillations in the hippocampus of the behaving rat. Neuron 2003, 37:311-322.

2. Pálhalmi J, Paulsen O, Freund TF, Hájos N: Distinct properties of carbacholand DHPG-induced network oscillations in hippocampal slices. Neuropharmacology 2004, 47:381-389. 
3. Morrosu F, Portas C, Mascia MS, Casu MA, Fà M, Giagheddu M, Imperato A, Gessa GL: Microdialysis measurement of cortical and hippocampal acetylcholine release during sleep-wake cycle in freely moving cats. Brain research 1995, 671:329-332.

4. Fisahn A, Pike FG, Buhl E, Paulsen O: Cholinergic induction of network oscillations at $40 \mathrm{~Hz}$ in the hippocampus in vitro. Nature 1998, 394:186-188.

5. Kopell N, Börgers C, Pervouchine D, Malerba P, Tort A: Gamma and Theta Rhythms in Biophysical Models of Hippocampal Circuits. Hippocampal Microcircuits, Springer Series in Computational Neuroscience 5 New York: Springer; 2010.

6. Akam T, Oren I, Mantoan L, Ferenczi E, Kullmann DM: Oscillatory dynamics in the hippocampus support dentate gyrus-CA3 coupling. Nature Neuroscience 2012, 15(5):763-768.

7. Pastoll H, Solanka L, van Rossum MCW, Nolan MF: Feedback Inhibition Enables Theta-Nested Gamma Oscillations and Grid Firing Fields. Neuron 2012, 77:141-154.

8. Colgin LL, Denninger T, Fyhn M, Hafting T, Bonnevie T, Jensen O, Moser M, Moser El: Frequency of gamma oscillations routes flow of information in the hippocampus. Nature 2009, 462:353-357.

doi:10.1186/1471-2202-16-S1-P267

Cite this article as: Betterton et al:: Modulation of hippocampal gamma oscillations by acetylcholine: insights from mathematical and in vitro optogenetic models. BMC Neuroscience 2015 16(Suppl 1):P267.

\section{Submit your next manuscript to BioMed Central and take full advantage of:}

- Convenient online submission

- Thorough peer review

- No space constraints or color figure charges

- Immediate publication on acceptance

- Inclusion in PubMed, CAS, Scopus and Google Scholar

- Research which is freely available for redistribution

Submit your manuscript at www.biomedcentral.com/submit 